\title{
PERSEPSI MASYARAKAT TERHADAP KEBERADAAN WARUNG KOPI DI KOTA BANDA ACEH
}

\author{
(Public Perception Of Coffee Shop Presence In Banda Aceh City) \\ Aufar Rivqi $^{1}$, Suyanti Kasimin ${ }^{1}$, Safrida ${ }^{{ }^{*}}$ \\ ${ }^{1}$ Program Studi Agribisnis, Fakultas Pertanian, Universitas Syiah Kuala
}

\begin{abstract}
Abstrak. Persepsi seseorang pada suatu objek di pengaruhi oleh 3 faktor yaitu faktor individu, target dan situasi. Penelitian ini bertujuan untuk mengetahui bagaimana persepsi masyarakat terhadap keberadaan warung kopi di Kota Banda Aceh. Penarikan sample diperoleh dengan metode Accidental Sampling dengan jumlah sampel sebanyak 50 responden. Metode yang digunakan adalah deskriptif kualitatif dan kuantitatif. Hasil penelitian ini menunjukan masyarakat memiliki persepsi bahwa keberadaan warung kopi sekarang ini menjadi salah satu ruang publik yang mampu memenuhi segala kebutuhan masyarakat dengan berbagai fasilitas-fasilitas yang ditawarkan dan berbagai menu makanan/minuman. Namun beberapa masyarakat memiliki persepsi bahwa dengan adanya warung kopi masyarakat menjadi lupa waktu hingga 3-5 jam berada di warung kopi dan bahkan tidak menggunakan fasilitas sebagai mana mestinya terutama bagi kalangan mahasiswa.
\end{abstract}

Kata Kunci : Persepsi, Warung Kopi, Faktor Individu, Faktor Target, Faktor Situasi

Abstract. A person's perception of an object is influenced by 3 factors, namely individual factors, targets and situations. This study aims to find out how people's perceptions of the existence of coffee shops in the city of Banda Aceh. Sample withdrawal is obtained by Accidental Sampling method with a total sample of 50 respondents. The method used is descriptive qualitative and quantitative. The results of this study indicate that the community has a perception that the existence of coffee shops is now one of the public spaces that can meet all the needs of the community with various facilities offered and various food / beverage menus. However, some people have the perception that with the community coffee shop, they will forget about 3-5 hours in a coffee shop and not even use the facilities as they should, especially for students.

Keywords: Perception, Coffee Shop, Individual Factor, Target Factor, Situation Factor

\section{PENDAHULUAN}

Kopi merupakan salah satu hasil komoditi perkebunan yang memiliki nilai ekonomis yang cukup tinggi di antara tanaman perkebunan lainnya dan berperan penting sebagai sumber devisa negara. Kopi tidak hanya berperan penting sebagai sumber devisa melainkan juga merupakan sumber penghasilan bagi tidak kurang dari satu setengah juta jiwa petani kopi di Indonesia (Rahardjo, 2012).

Banda Aceh sebagai Ibukota Provinsi Aceh memiliki warung kopi yang sedemikian banyak yang selalu ramai dikunjungi oleh konsumen dari berbagai lapisan masyarakat, seperti wisatawan domestik dan mancanegara.

Tabel 1. Jumlah Warung Kopi di Kota Banda Aceh

\begin{tabular}{cc}
\hline Tahun & Jumlah Warung Kopi (unit) \\
\hline 2013 & 100 \\
2014 & 114 \\
2015 & 200 \\
2016 & 226 \\
2017 & 233 \\
\hline
\end{tabular}

Sumber : Dinas Kebudayaan dan Pariwisata Kota Banda Aceh, 2017

*Corresponding author: Safrida@Unsyiah.co.id 
Kehadiran warung kopi di Kota Banda Aceh menjadi sebuah wadah yang dapat memberikan tempat bagi masyarakat Aceh pada umumnya untuk menjalin komunikasi satu sama lain. Warung kopi merupakan opsi masyarakat Kota Banda Aceh sebagai tempat perkumpulan, interaksi, dan memperoleh informasi. Sebagian orang mengunjungi warung kopi untuk mencari informasi (Mauriza, 1998). Pada dasarnya warung kopi di Aceh, hanya sebatas tempat perkumpulan orang-orang yang menikmati kopi. Tetapi semakin berkembangnya zaman dengan kehadiran warung kopi di Kota Banda Aceh sekarang ini, selain menjadikan tempat perkumpulan penikmat kopi dengan berbagai fasilitas yang ditawarkan, konsumen dapat melakukan berbagai aktifitas lain di warung kopi, baik berupa bisnis, pekerjaan, dan pembahasan perkuliahan.

Persepsi adalah kesan yang diperoleh oleh individu melalui panca indera dikelompokkan, kemudian individu tersebut memberi pendapat sehingga memperoleh hasil dari kesan tersebut, ada 3 faktor yang mempengaruhi persepsi seseorang yaitu faktor individu, target, dan situasi (Robbins, 2003).

Pada masa sekarang warung kopi di Kota Banda Aceh semakin banyak ditemukan dikarenakana proses globalisasi yang lebih maju (Rati Permata Sari, 2014:2). Salah satunya kehadiran wifi yang menjadi daya tarik sendiri sehingga warung kopi sekarang lebih menarik konsumen dan banyak menyediakan fasilitas lain seperti adanya ruangan VIP dan bisa digunakan untuk mengadakan rapat atau acara bagi sebagian masyarakat. Disamping itu warung kopi juga menjadi tempat favorit bagi masyarakat Aceh sendiri, baik untuk mengisi waktu luang atau membicarakan masalah pekerjaan dan perkuliahan. Perubahan yang signifikan atas jumlah dan bentuk warung kopi adalah salah satu masalah yang penting untuk diteliti.

Berdasarkan dari uraian pada latar belakang di atas maka rumusan permasalahan pada penelitian ini yaitu bagaimana persepsi masyarakat terhadap keberadaan warung kopi di Kota Banda Aceh. tujuan penelitian ini adalah untuk mengetahui bagaimana persepsi masyarakat terhadap keberadaan warung kopi di Kota Banda Aceh.

\section{Lokasi dan Waktu Penelitian}

\section{METODE PENELITIAN}

Penelitian ini dilakukan di Kota Banda Aceh, dimana penentuan lokasi dilakukan dengan metode purposive sampling. Purposive sampling adalah teknik pengambilan secara sengaja dan waktu penelitian dilakukan selama 30 hari dibagi 3 periode dalam sehari, yaitu pagi jam 08.00-10.00 WIB, siang jam 12.00-14.00 WIB, sore jam 15.0018.00 WIB.

\section{Objek dan Ruang Lingkup Penelitian}

Adapun objek dalam penelitian ini adalah konsumen yang menjadi pelanggan warung kopi. Ruang lingkup penelitian hanya terbatas pada persepsi yang merujuk faktor individu, faktor target, dan faktor situasi.

Teknik pengambilan sampel ditentukan dengan menggunakan teknik Accidental Sampling. Accidental Sampling adalah teknik penentuan sampel yang berdasarkan dengan kebetulan, yaitu responden yang kebetulan bertemu dengan peneliti dapat digunakan sebagai sampel bila dipandang orang tersebut cocok sebagai sumber data (Sugiyono, 2011). Sampel dalam penelitian ini adalah konsumen yang berada di warung kopi dan berjumlah sebanyak 50 orang responden.

Persepsi Masyarakat Terhadap Keberadaan Warung Kopi Di Kota Banda Aceh (Aufar Rivqi, 
Tabel 2 . Sampel Warung Kopi di Kota Banda Aceh

\begin{tabular}{c|l|c}
\hline No & Warung Kopi & Jumlah Responden \\
\hline 1 & Solong Ulee Kareng & 10 \\
2 & 3in1 & 10 \\
3 & Zakir Darussalam & 10 \\
4 & Taufik Lamdingin & 10 \\
5 & De Helsinki Lampineung & 10 \\
\hline
\end{tabular}

Sumber : Data Primer, 2017

\section{Sumber dan Metode Pengumpulan Data}

Data yang digunakan dalam penelitian ini adalah data primer dan data sekunder. Data primer adalah data yang diperoleh melalui wawancara dengan konsumen warung kopi sedangkan data sekunder diperoleh dari instansi terkait dan studi kepustakaan. Data tersebut nantinya digunakan dalam pengujian dan analisa dalam penelitian ini.

Metode analisis yang digunakan adalah deskriptif kualitatif dan kuantitatif untuk menjawab hipotesis pada penelitian ini menggunakan kuesioner, yaitu memberikan peluang kepada responden untuk mengekspresikan perasaan dalam bentuk jawaban mereka terhadap suatu pertanyaan.Kemudian untuk mengetahui bagaimana persepsi yang merujuk faktor individu, faktor target, faktor situasi terhadap keberadaan warung kopi di Kota Banda Aceh yaitu dengan menggunakan persentase sebagai berikut :

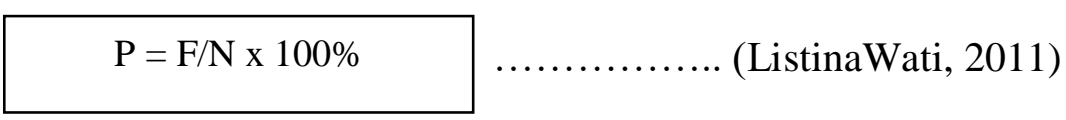

Keterangan :

$\mathrm{P}=$ Besarnya persentase pada faktor individu, faktor target dan faktor situasi

$\mathrm{F}=$ Frekuensi (jumlah jawaban responden)

$\mathrm{N}=$ Jumlah Responden

HASIL DAN PEMBAHASAN

Persepsi Masyarakat Kota Banda Aceh Terhadap Keberadaan Warung Kopi Berdasarkan Faktor Pemersepsi (individu)

Persepsi merupakan proses yang diperoleh oleh individu melalui panca indera kemudian individu tersebut memilih, mengatur dan menafsirkan sehingga memperoleh makna. Persepsi terhadap keberadaan warung kopi berdasarkan faktor individu merupakan kebutuhan, pengalaman, serta harapan seseorang dalam memandang suatu objek dan mencoba menafsirkan apa yang dilihatnya. Dalam hal ini faktor individu tersebut merupakan pandangan masyarakat kota Banda Aceh dalam menafsirkan keberadaan warung kopi. Berikut ini dapat dilihat hasil penelitian.

Tabel 3. Jumlah Persentase Berdasarkan Tujuan Masyarakat

\begin{tabular}{|c|c|c|c|c|c|c|c|}
\hline \multirow[t]{2}{*}{ No } & \multirow[t]{2}{*}{ Tujuan } & \multirow[t]{2}{*}{$\begin{array}{c}\text { Jumlah } \\
\text { Responden }\end{array}$} & \multicolumn{4}{|c|}{$\begin{array}{c}\text { Persentase } \\
\text { Jenis } \\
\text { Kelamin }\end{array}$} & \multirow[t]{2}{*}{$\begin{array}{l}\text { Persentase } \\
\text { Keseluruhan }\end{array}$} \\
\hline & & & $\mathrm{L}$ & $\mathrm{P}$ & $\mathrm{L}$ & $\mathrm{P}$ & \\
\hline 1. & Konsumsi Kopi & 15 & 14 & 1 & $28 \%$ & $2 \%$ & $30 \%$ \\
\hline 2. & $\begin{array}{l}\text { Berkumpul dengan } \\
\text { Rekan }\end{array}$ & 20 & 13 & 7 & $26 \%$ & $14 \%$ & $40 \%$ \\
\hline 3. & $\begin{array}{l}\text { Menggunakan Fasilitas } \\
\text { Wifi dan Ruang Rapat }\end{array}$ & 15 & 7 & 8 & $14 \%$ & $16 \%$ & $30 \%$ \\
\hline
\end{tabular}

Persepsi Masyarakat Terhadap Keberadaan Warung Kopi Di Kota Banda Aceh (Aufar Rivqi, 
Sumber: data primer (diolah), 2018

Berdasarkan tabel 3 dapat dilihat bahwa dari keseluruhan 50 responden tujuan masyarakat datang ke warung kopi untuk kategori berkumpul dengan persentase sebesar $40 \%$, kemudian untuk kategori mengkonsumsi kopi dengan persentase sebesar $30 \%$ dan untuk kategori menggunakan fasilitas sebesar 30\%. Dalam kata lain tujuan masyarakat datang ke warung kopi tidak hanya untuk menikmati kopi saja, tetapi warung kopi sudah menjadi ruang publik yang modern dan diminati oleh semua kalangan, selain itu masyarakat dapat menggunakan fasilitas yang telah disediakan. Kemudian persentase berdasarkan jenis kelamin dari keseluruhan 50 responden tujuan masyarakat untuk datang ke warung kopi untuk kategori berkumpul bagi kalangan laki-laki sebanyak 13 responden atau sebesar $26 \%$ sedangkan bagi kalangan perempuan sebanyak 7 responden atau sebesar 14\%, kemudian untuk kategori menikmati kopi bagi kalangan laki-laki sebanyak 14 responden atau sebesar 28\% sedangkan untuk kalangan perempuan sebanyak 1 responden atau sebesar 2\%, selanjutnya untuk kategori menggunakan fasilitas bagi kalangan lakilaki sebanyak 7 orang responden atau sebesar 14\% sedangkan bagi kalangan perempuan sebanyak 8 responden atau sebesar $16 \%$. Dalam hal ini bahwa masyarakat yang berkunjung ke warung kopi lebih dominan laki-laki, tetapi ada juga sebagian kalangan perempuan yang berkunjung ke warung kopi hanya untuk menggunakan fasilitas dan bahkan berkumpul dengan teman/rekan.

Tabel 4.Jumlah Persentase Berdasarkan Anggota Kerabat di Warung Kopi

\begin{tabular}{|c|c|c|c|c|c|c|c|}
\hline \multirow[t]{2}{*}{ No } & \multirow[t]{2}{*}{ Kerabat } & \multirow[t]{2}{*}{$\begin{array}{c}\text { Jumlah } \\
\text { Responden }\end{array}$} & \multicolumn{2}{|c|}{$\begin{array}{l}\text { Jenis } \\
\text { Kelamin }\end{array}$} & \multicolumn{2}{|c|}{$\begin{array}{l}\text { Persentase } \\
\text { Jenis } \\
\text { Kelamin }\end{array}$} & \multirow[t]{2}{*}{$\begin{array}{l}\text { Persentase } \\
\text { Keseluruhan }\end{array}$} \\
\hline & & & $\mathrm{L}$ & $\mathrm{P}$ & $\mathrm{L}$ & $\mathrm{P}$ & \\
\hline 1. & Teman & 40 & 31 & 9 & $62 \%$ & $18 \%$ & $80 \%$ \\
\hline 2. & Keluarga & 10 & 2 & 8 & $4 \%$ & $16 \%$ & $20 \%$ \\
\hline
\end{tabular}

Sumber: data primer (diolah), 2018

Berdasarkan tabel 4 dapat dilihat bahwa dari keseluruhan 50 responden, masyarakat berkunjung ke warung kopi untuk kategori bersama teman/kerabat dengan persentase sebesar $80 \%$ sedangkan untuk kategori bersama keluarga dengan persentase $10 \%$. Dalam hal ini masyarakat lebih memilih berkunjung ke warung kopi selepas jam kerja bersama teman/rekan karena pada saat tersebut bagi sebagian pekerja dapat bersantai bahkan ada hal khusus seperti mengikuti rapat, selain itu bagi kalangan mahasiswa dapat mengerjakan tugas bersama teman. Kemudian persentase berdasarkan jenis kelamin dari keseluruhan 50 responden masyarakat datang ke warung kopi untuk kategori bersama teman/kerabat bagi kalangan laki-laki sebanyak 31 responden atau sebesar $62 \%$ sedangkan bagi kalangan perempuan sebanyak 9 responden atau sebesar 18\%, kemudian bagi masyarakat yang berkunjung ke warung kopi bersama keluarga bagi kalangan lakilaki sebanyak 2 responden atau sebesar 4\% sedangkan bagi kalangan perempuan sebanyak 8 responden atau sebesar 16\%. Dalam hal ini masyarakat berkunjung ke warung kopi lebih dominan bersama teman/rekan kerja karena masyarakat dapat membicarakan masalah pekerjaan bagi sebagian pekerja, selain itu bagi sebagian mahasiswa/i dapat mengerjakan tugas kuliah bersama teman. Untuk kalangan IRT(ibu rumah tangga) lebih memilih bersama keluarga untuk datang ke warung kopi selain bisa menikmati fasilitas yang disediakan juga dapat menikmati menu-menu yang beragam.

Persepsi Masyarakat Terhadap Keberadaan Warung Kopi Di Kota Banda Aceh (Aufar Rivqi, 
Secara garis besar masyarakat mempunyai persepsi yang baik terhadap keberadaan warung kopi di Kota Banda Aceh karena pada dasarnya warung kopi tidak hanya untuk sekedar menikmati minuman kopi tetapi dalam perkembangannya warung kopi sudah menjadi ruang publik yang modern dan diminati oleh semua kalangan masyarakat Aceh, baik laki-laki maupun perempuan. Disamping itu juga ada beberapa responden yang mempunyai persepsi kurang baik karena masyarakat jika sudah berada di warung kopi lupa waktu bahkan bagi sebagian mahasiswa tidak masuk pada saat jam pelajaran berlangsung. Dari hasil penelitian masyarakat memiliki persepsi yang baik terhadap keberadan warung kopi karena pada zaman sekarang tidak hanya sekedar menikmati minuman kopi dan berbagai minuman lainnya tetapi juga untuk menggunakan fasilitas tambahan yang disediakan seperti wifi ataupun meeting room yang memudahkan bagi semua kalangan umur. Bahkan sebagian masyarakat memiliki tujuan yang khusus untuk berada di warung kopi seperti rapat bisnis, bertemu teman,mencari informasi dan mengerjakan tugas bagi sebagian mahasiswa/i.

\section{Persepsi Masyarakat Kota Banda Aceh Terhadap Keberadaan Warung Kopi Berdasarkan Faktor Target}

Persepsi terhadap keberadaan warung kopi berdasarkan faktor target merupakan karakteristik yang diamati dan akan mempengaruhi persepsi seseorang seperti pada penelitian ini ada beberapa karaktersitik yang dilihat atau diamati adalah hal apa yang menjadi pilihan pada suatu warung kopi dan faktor penting apa dalam memilih warung kopi. Berikut ini dapat dilihat hasil penelitian.

Tabel 5. Jumlah Persentase Faktor Penting Memilih Warung Kopi

\begin{tabular}{|c|c|c|c|c|c|c|c|}
\hline \multirow[t]{2}{*}{ No } & \multirow[t]{2}{*}{$\begin{array}{c}\text { Faktor Penting } \\
\text { Memilih Warung Kopi }\end{array}$} & \multirow[t]{2}{*}{$\begin{array}{c}\text { Jumlah } \\
\text { Responden }\end{array}$} & \multicolumn{2}{|c|}{$\begin{array}{c}\text { Jenis } \\
\text { Kelamin }\end{array}$} & \multicolumn{2}{|c|}{$\begin{array}{l}\text { Persentase } \\
\text { Jenis } \\
\text { Kelamin }\end{array}$} & \multirow[t]{2}{*}{$\begin{array}{l}\text { Persentase } \\
\text { Keseluruhan }\end{array}$} \\
\hline & & & $\mathrm{L}$ & $\mathrm{P}$ & $\mathrm{L}$ & $\mathrm{P}$ & \\
\hline 1. & Lokasi & 8 & 4 & 4 & $8 \%$ & $8 \%$ & $16 \%$ \\
\hline 2. & Fasilitas & 18 & 14 & 4 & $28 \%$ & $8 \%$ & $36 \%$ \\
\hline 3. & $\begin{array}{l}\text { Pilihan } \\
\text { Makanan/minuman }\end{array}$ & 24 & 16 & 8 & $32 \%$ & $16 \%$ & $48 \%$ \\
\hline
\end{tabular}

Sumber: data primer(diolah), 2018

Berdasarkan tabel 5 dapat dilihat bahwa dari keseluruhan 50 responden, hal penting masyarakat dalam memilih warung kopi untuk kategori Lokasi/jarak sebanyak 8 responden atau sebesar $16 \%$ kemudian untuk hal penting berdasarkan kategori fasilitas sebanyak 18 responden atau sebesar 36\% dan untuk kategori pilihan makanan/minuman sebanyak 24 responden atau sebesar $48 \%$. Dalam hal ini faktor penting masyarakat dalam memilih warung kopi karena pada warung kopi tersedia makanan/minuman yang beragam selain itu masyarakat juga dapat menikmati fasilitas yang disediakan oleh pihak warung kopi tersebut. Kemudian persentase berdasarkan jenis kelamin dari keseluruhan 50 responden hal penting masyarakat dalam memilih warung kopi untuk kategori lokasi bagi kalangan laki-laki sebanyak 4 responden atau sebesar $8 \%$ sedangkan bagi kalangan perempuan sebanyak 4 responden atau sebesar $8 \%$, kemudian hal penting untuk kategori fasilitas bagi kalangan laki-laki sebanyak 14 responden atau sebesar $28 \%$ sedangkan untuk kalangan perempuan sebanyak 4 responden atau sebesar $8 \%$, selanjutnya untuk kategori pilihan menu makanan/minuman bagi kalangan laki-laki sebanyak 16 responden atau sebesar $32 \%$ sedangkan bagi kalangan perempuan sebanyak 8 responden atau

Persepsi Masyarakat Terhadap Keberadaan Warung Kopi Di Kota Banda Aceh (Aufar Rivqi, 
sebesar 16\%. Dalam hal ini bahwa faktor penting masyarakat dalam memilih warung kopi karena tersedia berbagai menu makanan/minuman walaupun pada dasarnya adalah kopi, tetapi bagi kalangan perempuan berkunjung ke warung kopi selain menggunakan fasilitas juga menikmati menu yang tersedia.

Dari hasil penelitian masyarakat untuk memilih warung kopi karena sebagai tempat pusat informasi yang efektif dan efesien, masyarakat juga memanfaatkan warung kopi sebagai tempat rapat serta mengerjakan tugas bagi sebagian mahasiswa. Kemudian hal terpenting dalam memilih warung kopi adalah banyak pilihan menu, fasilitas yang memadai serta warung kopi yang di kunjungi tidak terlalu jauh dengan rumah/kantor/kampus. Dapat disimpulkan bahwa masyarakat Kota Banda Aceh memilih warung kopi karena pada dasarnya warung kopi tidak hanya menyediakan minuman kopi saja, tetapi semakin berkembangnya zaman warung kopi sudah menyediakan berbagai pilihan menu makanan/minuman selain itu masyarakat juga dapat menikmati fasilitas fasilitas seperti wifi, ruang rapat.

\section{Persepsi Masyarakat Kota Banda Aceh Terhadap Keberadaan Warung Kopi Berdasarkan Faktor Situasi}

Persepsi merupakan proses yang diperoleh oleh individu melalui panca indera kemudian individu tersebut memilih, mengatur dan menafsirkan sehingga memperoleh makna. Persepsi masyarakat terhadap warung kopi berdasarkan faktor situasi merupakan hal apa yang dilihat atau diamati oleh masyarakat terhadap warung kopi untuk mempengaruhi persepsi seseorang. Berikut ini dapat dilihat hasil penelitian.

Tabel 6. Jumlah Persentase Situasi Pada Warung Kopi

\begin{tabular}{|c|c|c|c|c|c|c|c|}
\hline \multirow[t]{2}{*}{ No } & \multirow[t]{2}{*}{ Situasi } & \multirow[t]{2}{*}{$\begin{array}{c}\text { Jumlah } \\
\text { Responden }\end{array}$} & \multicolumn{2}{|c|}{$\begin{array}{c}\text { Jenis } \\
\text { Kelamin }\end{array}$} & \multicolumn{2}{|c|}{$\begin{array}{l}\text { Persentase } \\
\text { Jenis } \\
\text { Kelamin }\end{array}$} & \multirow[t]{2}{*}{$\begin{array}{c}\text { Persentase } \\
\text { Keseluruhan }\end{array}$} \\
\hline & & & $\mathrm{L}$ & $\mathrm{P}$ & $\mathrm{L}$ & $\mathrm{P}$ & \\
\hline 1. & Ramai & 28 & 20 & 8 & $40 \%$ & $16 \%$ & $56 \%$ \\
\hline 2. & Nyaman & 15 & 13 & 2 & $26 \%$ & $4 \%$ & $30 \%$ \\
\hline 3. & Ribut & 7 & 1 & 6 & $2 \%$ & $12 \%$ & $14 \%$ \\
\hline
\end{tabular}

Sumber: data primer (diolah), 2018

Berdasarkan tabel 6 dapat dilihat bahwa dari keseluruhan 50 responden, situasi pada warung kopi untuk kategori ramai sebanyak 28 responden atau sebesar 56\% kemudian situasi pada warung kopi untuk kategori nyaman sebanyak 15 responden atau sebesar $30 \%$ dan untuk kategori ribut sebanyak 7 responden atau sebesar $14 \%$. Dalam hal ini situasi yang terjadi pada warung kopi ramai dengan pembicaraan segala hal, tetapi walaupun demikian situasi tersebut tidak menjadi penghalang bagi sebagian masyarakat bahkan merasa santai dan nyaman pada saat berada di warung kopi walaupun terlihat ramai. Pada dasarnya masyarakat berkunjung ke warung kopi tidak hanya untuk menikmati kopi melainkan untuk membicarakan masalah pekerjaan, kuliah, bisnis, dan lain sebagainya, jadi tidak heran bahwa situasi yang terlihat ramai akan perbincangan. Kemudian persentase berdasarkan jenis kelamin dari keseluruhan 50 responden. Situasi pada warung kopi untuk kategori ramai bagi kalangan laki-laki sebanyak 20 responden atau sebesar $40 \%$ sedangkan bagi kalangan perempuan sebanyak 8 responden atau sebesar $16 \%$, kemudian situasi pada warung kopi untuk kategori santai/nyaman bagi kalangan laki-laki sebanyak 13 responden atau sebesar 26\% sedangkan untuk kalangan perempuan sebanyak 2 responden atau sebesar 4\%, selanjutnya untuk kategori ribut/berisik bagi

Persepsi Masyarakat Terhadap Keberadaan Warung Kopi Di Kota Banda Aceh (Aufar Rivqi, 
kalangan laki-laki sebanyak 1 responden atau sebesar $2 \%$ sedangkan bagi kalangan perempuan sebanyak 6 responden atau sebesar 12\%. Dalam hal ini situasi yang terjadi pada warung kopi ramai dengan segala pembicaraan masyarakat, tetapi bukan menjadi sebuah penghalang bagi sebagian masyarakat hanya saja untuk kalangan perempuan mungkin akan sedikit tidak nyaman karena situasi yang ramai dan ribut namun demikian warung kopi tidak lepas dari banyak perbincangan.

Tabel 7. Jumlah Persentase Pelayanan dan Fasilitas Pada Warung Kopi

\begin{tabular}{|c|c|c|c|c|c|c|c|}
\hline \multirow[t]{2}{*}{ No } & \multirow[t]{2}{*}{$\begin{array}{l}\text { Pelayanan dan } \\
\text { Fasilitas }\end{array}$} & \multirow[t]{2}{*}{$\begin{array}{c}\text { Jumlah } \\
\text { Responden }\end{array}$} & \multicolumn{2}{|c|}{$\begin{array}{c}\text { Jenis } \\
\text { Kelamin }\end{array}$} & \multicolumn{2}{|c|}{$\begin{array}{l}\text { Persentase } \\
\text { Jenis } \\
\text { Kelamin }\end{array}$} & \multirow[t]{2}{*}{$\begin{array}{c}\text { Persentase } \\
\text { Keseluruhan }\end{array}$} \\
\hline & & & $\mathrm{L}$ & $\mathrm{P}$ & $\mathrm{L}$ & $\mathrm{P}$ & \\
\hline 1. & Sesuai & 35 & 25 & 10 & $50 \%$ & $20 \%$ & $70 \%$ \\
\hline 2. & Tidak Semua & 15 & 8 & 6 & $16 \%$ & $12 \%$ & $30 \%$ \\
\hline
\end{tabular}

Berdasarkan tabel 7 dapat dilihat bahwa dari keseluruhan 50 responden, pelayanan maupun fasilitas pada warung kopi untuk kategori sesuai sebanyak 35 responden atau sebesar 70\% kemudian pelayanan maupun fasilitas pada warung kopi untuk kategori tidak semua warung kopi sebanyak 15 responden atau sebesar 30\%. Dalam hal ini pelayanan maupun fasilitas pada warung kopi di Kota Banda Aceh sudah sesuai dengan perkembangan zaman, masyarakat akan memilih warung kopi yang memiliki pelayanan dan fasilitas memadai karena pada zaman sekarang fasilitas seperti wifi akan sangat berguna bagi masyarakat terutama bagi kalangan pekerja dapat menggunakan fasilitas tersebut untuk mencari segala informasi dan bahkan bagi sebagian mahasiswa/i dapat memudahkan untuk mengerjakan tugas kuliah. Tetapi situasi yang memadai tidak semua warung kopi sesuai karena masih ada warung kopi yang tidak menggunakan fasilitas tersebut. Kemudian persentase berdasarkan jenis kelamin dari keseluruhan 50 responden. Pelayanan maupun fasilitas pada warung kopi untuk kategori sesuai bagi kalangan lakilaki sebanyak 25 responden atau sebesar $50 \%$ sedangkan bagi kalangan perempuan sebanyak 10 responden atau sebesar $20 \%$, kemudian pelayanan maupun fasilitas pada warung kopi untuk kategori tidak semua warung kopi bagi kalangan laki-laki sebanyak 8 responden atau sebesar $16 \%$ sedangkan untuk kalangan perempuan sebanyak 6 responden atau sebesar $12 \%$. Dalam hal ini pelayanan maupun fasilitas sudah sesuai karena bagi sebagian masyarakat beranggapan bahwa semua warung kopi sudah memiliki fasilitas yang memadai, namun demikian ada beberapa masyarakat yang berpendapat bahwa tidak semua warung kopi memiliki pelayanan dan fasilitas yang memadai tetapi secara garis besar warung kopi di Kota Banda Aceh sekarang sudah lengkap dan sesuai pada zamannya.

Dari hasil penelitian alasan mengenai situasi pada warung kopi yaitu situasi yang berlangsung ketika berada di warung kopi ramai dengan pembicaraan segala hal, kemudian alasan masyarakat memilih warung kopi bukan hanya dari citarasa kopi ataupun fasilitas wifi saja, tetapi keamanan pada warung kopi baik itu keamanan pada kendaraan, maupun keamanan pada lokasi parkir adalah salah satu faktor terpenting masyarakat untuk datang ke warung kopi. Dapat disimpulkan bahwa situasi yang ramai dan ribut pada warung kopi tidak menjadi penghalang bagi masyarakat untuk berkunjung ke warung kopi, bahkan ada sebagian masyarakat yang melihat pelayanan maupun

Persepsi Masyarakat Terhadap Keberadaan Warung Kopi Di Kota Banda Aceh (Aufar Rivqi, 462 
fasilitas pada warung kopi, seiring berkembangnnya zaman masyarakat memilih warung kopi yang memiliki fasilitas maupun pelayanan yang memadai karena hal tersebut dapat membantu sebagian masyarakat yang memerlukan, bahkan bagi kalangan mahasiswa/i akan sangat berpengaruh untuk berkunjung ke warung kopi yang memiliki fasilitas memadai melainkan untuk mengerjakan tugas maupun untuk mencari informasi bagi sebagian pekerja.

\section{Persepsi Masyarakat Terhadap Keberadaan Warung Kopi di Kota Banda Aceh}

Masyarakat memiliki tujuan ke warung kopi untuk berkumpul bersama teman/rekan kerja dengan persentase sebesar $40 \%$ ini membuktikan bahwa warung kopi tidak hanya tempat untuk menikmati minuman kopi saja melainkan sudah menjadi ruang publik yang modern dan diminati oleh masyarakat, selain itu masyarakat juga dapat menggunakan fasilitas-fasilitas yang disediakan terutama bagi kalangan mahasiswa dapat menggunakan fasilitas wifi untuk mengerjakan tugas dan bahkan mencari segala informasi. Warung kopi pada era sekarang memiliki pelayanan yang mampu memberikan tempat tanpa batasan waktu yang dapat dijadikan tempat untuk membangun pertumbuhan ekonomi masyarakat Kota Banda Aceh. sebagian besar masyarakat Kota Banda Aceh lebih memilih berkunjung ke warung kopi bersama teman selepas jam kerja, karena pada saat tersebut bagi sebagian pekerja seperti PNS dan wiraswasta dapat beristirahat dengan menikmati menu-menu yang ditawarkan dan bagi sebagian mahasiswa dapat mengerjakan tugas serta mencari informasi.

Warung kopi salah satu tempat untuk mencari informasi yang efektif dan efesien dengan adanya fasilitas-fasilitas tambahan dengan berbagai menu yang ditawarkan dan dekorasi pada bangunannya. Masyarakat lebih memilih warung kopi yang menyediakan berbagai menu makanan/minuman dengan persentase sebesar $48 \%$ ini membuktikan bahwa warung kopi sekarang sudah berbeda dengan warung kopi dahulu, dahulu warung kopi hanya sekedar tempat untuk menikmati minuman kopi, tetapi sekarang pada warung kopi sudah tersedia menu makanan/minuman sehingga lebih menarik minat masyarakat dan bagi para pekerja maupun mahasiswa dapat menikmati pada saat waktu istirahat. Kemudian fasilitas yang memadai dan lokasi warung kopi yang tidak terlalu jauh dengan rumah/kantor/kampus menjadi salah satu hal terpenting masyarakat dalam memilih warung kopi yang ingin dikunjungi.

Warung kopi di Kota Banda Aceh tidak luput dari pembicaraan segala hal mulai dari masalah pribadi hingga masalah politik menjadi salah satu bahan perbincangan masyarakat. Sebagian besar masyarakat berpendapat bahwa situasi pada warung kopi yang ramai akan pembicaraan dengan persentase sebesar $56 \%$, namun demikian hal tersebut tidak menjadi sebuah penghalang bagi masyarakat untuk berkunjung ke warung kopi. Bahkan ada sebagian masyarakat yang lebih melihat pelayanan maupun fasilitas pada warung kopi dengan persentase sebesar $70 \%$, seiring berkembangnya zaman masyarakat memilih warung kopi yang memiliki fasilitas maupun pelayanan yang memadai karena pelayanan yang baik, ramah maupun cepat dapat membuat konsumen merasa nyaman jika berada di warung kopi. selanjutnya fasilitas-fasilitas yang memadai akan sangat berpengaruh terhadap konsumen, karena bagi sebagian mahasiswa/i dapat mengerjakan tugas maupun mencari segala informasi.

Pada masa sekarang, warung kopi menjadi salah satu tempat yang dibuat sedemikian nyaman, dengan adanya fasilitas-fasilitas tambahan dan dekorasi pada bangunannya. Keberadaan warung kopi sekarang ini menjadi salah satu ruang publik

Persepsi Masyarakat Terhadap Keberadaan Warung Kopi Di Kota Banda Aceh (Aufar Rivqi, 
yang diminti oleh segala masyarakat terutama bagi sebagian pekerja seperti PNS, wiraswasta muda dan mahasiswa karena warung kopi dapat dijadikan tempat untuk rapat dan bahkan mencari segala informasi. Sebagian besar masyarakat berpendapat bahwa warung kopi sekarang ini sudah berbeda dengan warung kopi dahulu, dahulu warung kopi hanya di jadikan tempat untuk menikmati minuman kopi saja dan dekorasidekorasinya pun tidak mempunyai fasilitas-fasilitas yang memadai, tetapi sekarang ini warung kopi sudah memiliki segala fasilitas-fasilitas untuk memudahkan masyarakat dan bahkan pada warung kopi pun dapat dijadikan tempat untuk berbisnis serta mencari segala informasi, menu makanan dan minuman sudah beragam sehingga masyarakat dapat beristirahat selepas jam kerja atau kuliah. Namun ada bebarapa masyarakat berpendapat bahwa jika sudah berada di warung kopi masyarakat akan lupa waktu terutama bagi mahasiswa.

\section{SIMPULAN DAN SARAN}

\section{Simpulan}

Adapun simpulan dari penelitian ini adalah masyarakat memiliki tujuan ke warung kopi untuk berkumpul berasama teman/rekan dengan persentase $40 \%$ selanjutnya masyarakat lebih memilih warung kopi yang memiliki beragam menu makanan/minuman dengan persentase $48 \%$, kemudian masyarakat berpendapat bahwa situasi yag terjadi pada warung kopi ramai akan perbincangan segala hal dengan persentase $56 \%$ dan sebagian masyarakat lebih melihat pelayanan maupun fasilitas pada warung kopi dengan persentase sebesar 70\%. Masyarakat memiliki persepsi bahwa keberadaan warung kopi sekarang ini menjadi salah satu ruang publik yang mampu memenuhi segala kebutuhan masyarakat dengan berbagai fasilitas-fasilitas yang ditawarkan dan berbagai menu makanan/minuman. Namun beberapa masyarakat memiliki persepsi bahwa dengan adanya warung kopi masyarakat menjadi lupa waktu hingga 3-5 jam berada di warung kopi dan dan bahkan tidak menggunakan fasilitas sebagai mana mestinya terutama bagi kalangan mahasiswa.

\section{Saran}

Adapun saran yang dapat peneliti berikan adalah untuk konsumen warung kopi terutama mahasiswa agar dapat mengatur waktu dengan baik sesuai dengan kebutuhan sehingga tidak lupa waktu pada saat berada di warung kopi dan dapat menggunakan fasilitas-fasilitas hanya untuk kepentingan. Selanjutnya bagi pemilik warung kopi yang belum memiliki fasilitas yang memadai agar dapat memberikan fasilitas yang sesuai, sehingga memiliki keuntungan tersendiri bagi pemilik warung kopi.

\section{DAFTAR PUSTAKA}

Andiriadi. 2011. Persepsi Masyarakat Terhadap Keberadaan Kafe Remang-Remang (Studi Deskriptif di Kel. Sunggal, Kec. Medan Sunggal, Medan). Skripsi, Fakultas Ilmu Sosial dan Politik. Universitas Sumatera Utara.

Badan Pusat Statistik. 2017. Banda Aceh Dalam Angka. Tahun 2017.

Bimo, Walgito. 1981. Pengantar Psikologi Umum. diterbitkan oleh Yayasan Penerbitan Fakultas Psikologi UGM, Yogyakarta.

Persepsi Masyarakat Terhadap Keberadaan Warung Kopi Di Kota Banda Aceh (Aufar Rivqi, 
Bimo, Walgito. 2002. Pengantar Psikologi Umum. Yogyakarta: Andi, Jakarta.

Bimo, Walgito, 2004. Pengantar Psikologi Umum, Andi, Jakarta.

Dinas Kebudayaan, dan Pariwisata, 2017. Jumlah Warung Kopi di Kota Banda Aceh. Dinas Kebudayaan dan Pariwisata Kota Banda Aceh, Tahun 2017.

Dirman. 2017. Respon Masyarakat Terhadap Keberadaan Café Remang-Remang Di Bukit Betapuh Desa Kasang Kecamatan KUantan Mudik Kabupaten Kuantan Singingi. Jom Fisip Vol. 4 No. 1 Februari 2017.

Fred Luthans. 2006. Perilaku Organisasi. Edisi 10. Andi: Yogyakarta.

Gelora Cita. 2015. Studi Tentang Fungsi Warung Kopi Bagi Masyarakat di Kota Bagansiapiapi. Jom Fisip Vol.2 No.2 Oktober 2015.

Kotler, Philip. 1991. Manajemen Pemasaran, Analisis, Perencanaan, Implementasi dan Pengendalian. Jakarta: Erlangga .

Kotler, Philip. 2003. Manajemen Pemasaran. Edisi Keseblas, Jakarta: Indeks.

Listinawati, E. 2011. Partisipasi Petani Dalam Pengembangan Usaha Agribisnis Pedesaan (PUAP) di Kab. OKU. Jurnal Agronobis Vol.3 No.5 Maret 2011.

Mauriza, Sazli. 1998. Warung Kopi dalam Kehidupan Sosial Masyarakat Aceh. Skripsi. Yogyakarta. Fakultas Ilmu Budaya Universitas Gadjah Mada Yogyakarta.

Miftah, Thoha. 2007. Kepemimpinan Dalam Manajemen. Jakarta: PT. Raja Grafindo Persada.

Miftah, Thoha. 2010. Kepemimpinan Dalam Manajemen, Jakarta : Rajawali Pers.

Miswar Muhammad. 2017. Pengaruh Wifi (Wireless Fidelity) Terhadap Pengunjung Warung Kopi di Kota Banda Aceh, skripsi. Fakultas Adab UIN Ar-Raniry Banda Aceh.

Muammar. 2018. Perkembangan Warung Kopi di Kota Banda Aceh Dari Tahun (19742017). Skripsi. Fakultas Keguruan dan Ilmu Pendidikan Universitas Syiah Kuala Banda Aceh.

Notoatmodjo. 2010. Metodologi Penelitian Kesehatan. Jakarta : PT. Rineka Cipta.

Novitayani. 2014. Warung Kopi Sebagai Sarana Komunikasi dan Sumber Informasi Bagi Profesi Wartawan. Thesis, Jurusn Ilmu Komunikasi. Fakultas Ilmu Sosial dan Ilmu Politik Universitas Sumatera Utara. Medan.

Nurcholis, 2010, Administrasi Pemerintah Daerah., Universitas terbuka, Jakarta.

Nurlaila Hayati. 2015. Eksistensi Pengguna WI-FI di Warung Kopi di Kota Banda Aceh. Junal Al-Ijtimayyah Vol.1 No.1 Januari-Juni 2015.

Pareek, Udai,1986. Prilaku Organisasi, Jakarta : PT Pustaka Binaman Pressindo, 
Polak, Major. 1976. Sosiologi Suatu Buku Pengantar Ringkas. Ichtiar. Jakarta.

Rahardjo, Pudji. 2012. Panduan Budidaya dan Pengolahan Kopi Arabika dan Robusta. Penebar Swadaya: Jakarta.

Rakhmat, Jalaluddin, 2005. Psikologi Komunikasi. Bandung: PT. Remaja Rosdakarya.

Rakhmat, Jalaluddin, 2007. Metode Penelitian Komunikasi. Bandung: PT. Remaja Rosdakarya.

Rani Permata Sari. 2014. Perempuan dan Warung Kopi (Analisis Terhadap Perilaku Perempuan dan Persepsi Masyarakat Kota Banda Aceh). Skripsi. Fakultas Hukum Universitas Syiah Kuala Banda Aceh.

Riza Aulia Putra. 2015. Interpretasi Makna Pada Warung Kopi Aceh (Studi Kasus: Warung Kopi Solong di Banda Aceh). Skripsi. Sekolah Arsitektur, Perencanaan dan Pengembangan Kebijakan, Institut Teknologi Bandung.

Robbins, Stephen P. 1996. Perilaku Persepsi, Konsep, Kontroversi dan Aplikasi. Alih Bahasa : Hadyana Pujaatmaka. Edisi Keenam. Penerbit PT.Bhuana Ilmu Populer, Jakarta.

Robbins, Stephen P, 2003. Perilaku Persepsi, Jilid 2, PT. Indeks Kelompok Gramedia, Jakarta.

Robbins, Stephen P, Timothy A. Judge 2008. Perilaku Persepsi, PT. Salemba Empat, Jakarta.

Sistaningrum, 2002, Manajemen Promosi Pemasaran. Jakarta : PT Index, 98.

Sobur, Alex, 2009. Psikologi Umum, Bandung : Pustaka Setia Bandung.

Soekartawi. 2002. Analisis Usahatani. Jakarta: Universitas Indonesia.

Sugiyono. 2007. Metodologi Penelitian Bisnis, PT. Gramedia, Jakarta.

Sugiyono. 2011. Metode Penelitian Kuantitatif, Kualitatif dan R\&D. Bandung:Alfabeta.

Susantaro dalam Ramdha. 1990:23. Manajemen Mutu Berbasis Sekolah. Bandung : Sarana Panca Karya Nusa.

Thantawy. 2005. Kamus Istilah Bimbingan dan Konseling. Jakarta: Grasindo. 